\begin{tabular}{ll}
\hline 臨 & 床 \\
\hline
\end{tabular}

\title{
一側性感音難聴が初発症状の橋部に発生した髄芽腫例
}

\author{
佐藤 斎・藤㠃 俊之・和田 匡史 \\ 窪田和・泉修司・高橋姿
}

\section{Brainstem Medulloblastoma Manifesting as Low-tone Sensorineural Hearing Loss}

\author{
Hitoshi Satoh, Toshiyuki Fujisaki, Tadashi Wada, \\ Yamato Kubota, Shuji Izumi and Sugata Takahashi \\ (Niigata University, School of Medicine)
}

\begin{abstract}
Medulloblastoma is the most common childhood primary central nervous system tumor. In adults, most medulloblastomas occur in patients younger than 40. Common symptoms are cerebellar dysfunction and signs of CSF flow obstruction.

This report describes the case of a 25 -year-old female who presented with progressive unilateral sensorineural hearing loss (SNHL) as the first symptom of a medulloblastoma in the right inferior cerebellar peduncle and pons. She was referred to an ENT outpatient clinic, and diagnosed with right low tone-dominant SNHL. Her right SNHL progressed with an additional symptom, left moderate facial palsy, 7 months later, and she consequently visited the clinic again. She was introduced to our clinic for further examination. At that time, magnetic resonance imaging (MRI) revealed a right brainstem lesion. The ipsilateral stapedial reflex was normal in the right ear but absent in the left. Bekesy audiometry was type III. Electronystagmography showed a spontaneous nystagmus to the left and saccade pursuit. The auditory brainstem response was absent in the right ear.

The presented case showed that unilateral SNHL can be the first symptom of a brainstem tumor lesion. Progressive SNHL cases should be checked by MRI, in order to exclude brainstem lesions just like cerebello-pontine angle lesions.
\end{abstract}

Key words : medulloblastoma, sensorineural hearing loss, MRI

\section{はじめに}

蝸牛神経核から末梢の病変は，一側の感音難聴の原因 となりうる。しかしながら蝸牛神経核は，三叉神経核， 外転神経核, 顔面神経核, 前庭神経核と近接するため, 螖牛神経核が単独で傷害される脳幹病変はまれである. 一方, 蝸牛神経核より中枢側の聴覚伝導路は上行線維と 交差線維に分かれるため，両側にまたがる広範な病変が
生じないと純音聴力検査では異常を示さない. そうした 場合, 脳幹のダメージは大きく生命予後は不良となるた め，同様に一側の感音難聴が主症状となることはまれで ある。

われわれは，右感音難聴が初発症状の橋髄芽腫症例を 経験したので報告する.本症例では前医初診時に MRI 検 查が施行され脳幹の異常陰影はすでに描出されていたに 
もかかわらず, 初診の 9 力月後に難聴の増悪と顔面麻痺 が出現し当科において再検討されるまで異常として認識 されなかった。診断が遅れた経緯を見直し問題点を検討 するとともに，一側性の感音難聴が初発症状となる脳幹 腫瘍性病変について考察した.

\section{症例}

症 例 : 25 歳, 女性.

主 訴：右難聴，右顔面麻痺.

既往歴：特記すべきものなし.

家族歴：父, 大腸癌.

現病歴：2004 年 5 月頃より右難聴を自覚し始め, 以後 徐々に進行したため 2005 年 2 月 15 日に前医を受診した. その際右低音障害型感音難聴を指摘され（図 1），頭部 MRI を施行したが, 小脳橋角部には異常なく, その他の 病変も指摘されず，経過観察となった。 9 月上旬になっ て右顔面の違和感が出現したため, 前医を再診し, 右感 音難聴増悪と右顔面神経麻痺が認められた。右耳鳴を自 覚したが，めまいはなかった． 9 月 29 日，精查目的に当 科を紹介され受診した。

受診時所見：両側鼓膜は正常で, 耳介疱疹や口腔内ア フタ, 水疮疹はなく, 鼻咽喉頭, 眼, 皮膚に異常所見は 認められなかった。

耳鼻咽喉科学的検查所見: 純音聴力検查では, 右気導 聴力閾值は $70 \sim 80 \mathrm{~dB}$ で $250 \mathrm{~Hz}$ から $1000 \mathrm{~Hz}$ に約 $20 \mathrm{~dB}$ の気導骨導閾値差を伴う水平型混合性難聴を認めた（図 2). 左聴力閾値は正常であった。語音聴力検查では, 語

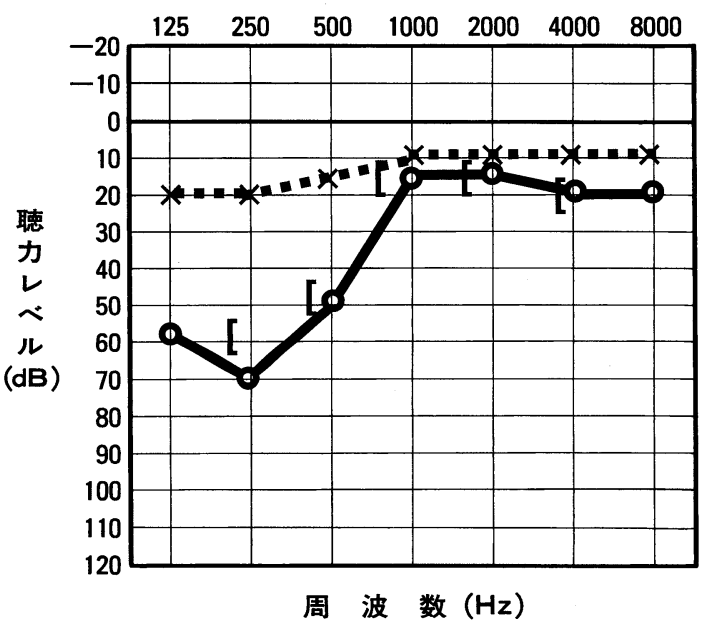

図 1 前医受診時のオージオグラム（2005 年 2 月 15 日）
音了解閾値は右 $85 \mathrm{~dB}$ ，左 $10 \mathrm{~dB}$ ，語音弁別能は右 $80 \%$, 左 $100 \%$ であった．SISI 検査は右 $5 \%(500 \mathrm{~Hz} ）$ （左は正 常聴力のため検査せず), 自記オージオメトリー検査では 右 Jerger 分類 III 型 $(4000 \mathrm{~Hz})$, 左 Jerger 分類 V 型 $(1000 \mathrm{~Hz})$ であった。聴性脳幹反応検查（ABR）は日本 光電工業株式会社製, 誘発電位筋電図検查装置MEM4104 により音圧 $100 \mathrm{dBSPL}$ のクリック音刺激にて行い，右は 再現性のある各波を認めず無反応，左は波形，潜時とも 正常であった（図 3)。平衡機能検査では，左向き水平性 自発，頭位眼振を認め，視標追跡運動では水平方向，垂

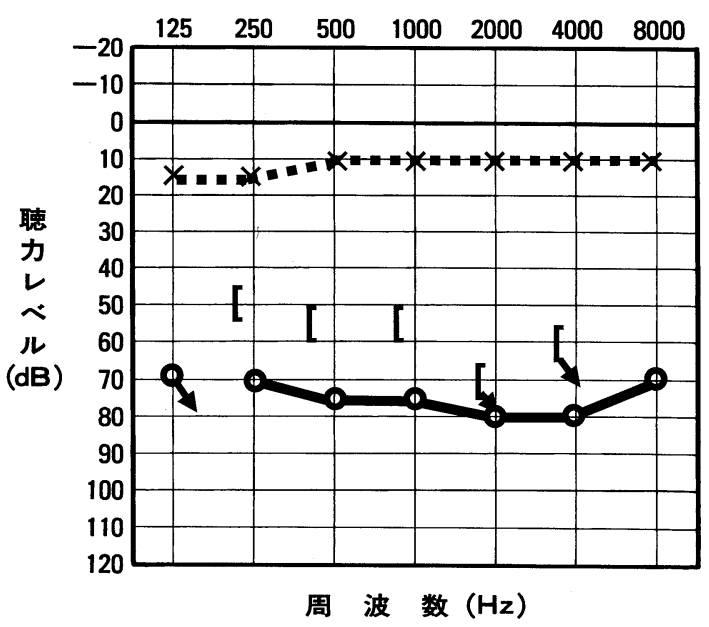

図 2 当科受診時のオージオグラム（2005 年 9 月 29 日）

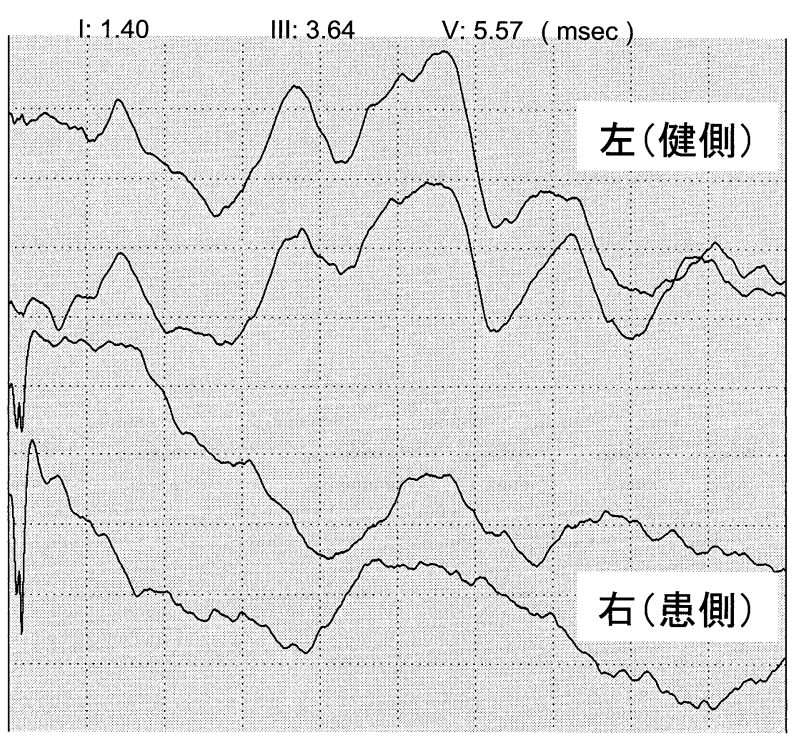

図 3 聴性脳幹反応検查結果 (両耳 $100 \mathrm{dBSPL}$ クリック音刺激) 

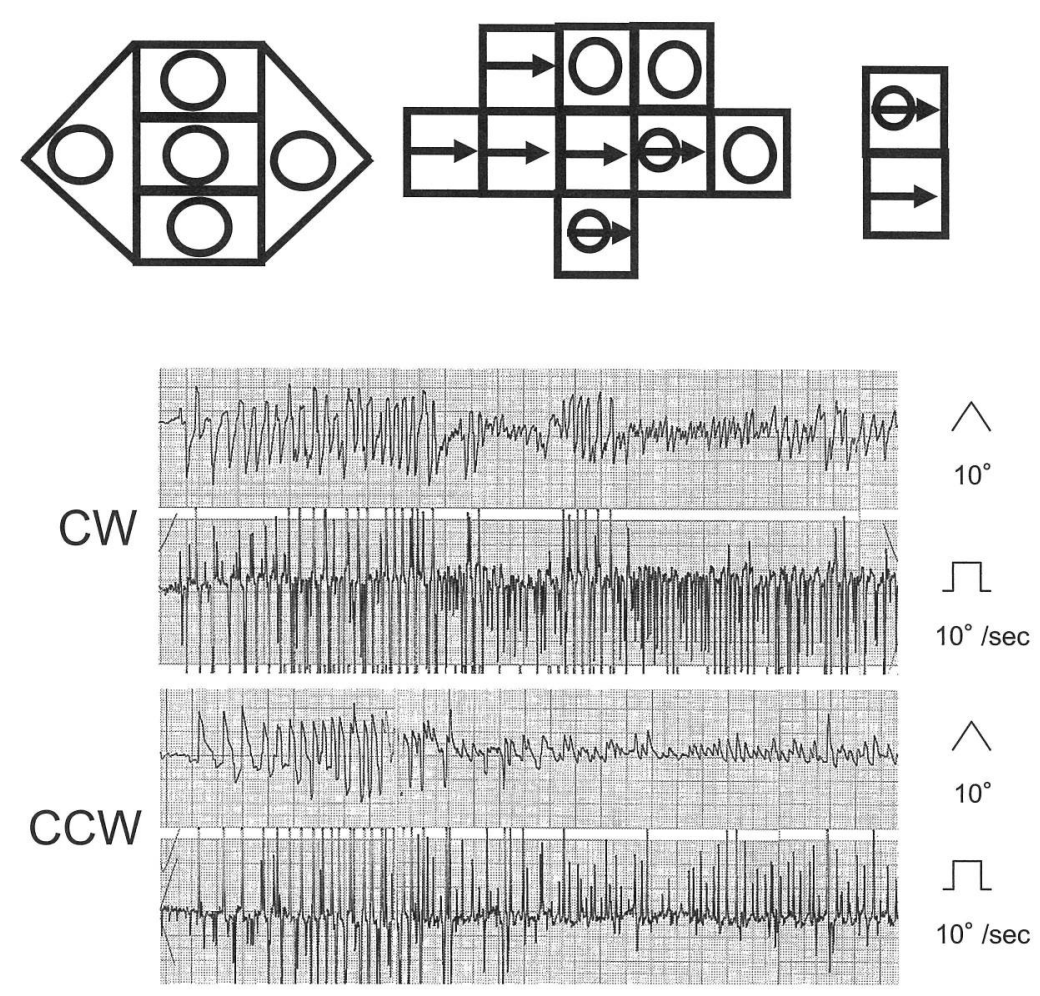

図 4 眼振所見と $\mathrm{OKN}$ 結果

直方向 saccadic, 視運動性眼振検查は眼振の解発が不良 であった（図 4)。

神経学的検查所見: 顔面神経検查では, 右表情筋スコ アは 20/40 点で（額しわ奇せ 2/4）, あぶみ骨筋反射は右 耳の音響刺激では両耳とも陰性, 左側刺激では両耳とも 陽性であった. Nerve excitability test（NET）では左右差 なく, Electroneurography（ENoG）む51.4\%で脱神経の 所見は得られなかった. その他, 眼球運動は正常, 顔面 知覚には左右差なく, 咽頭反射正常, 舌運動正常であっ た. 上下肢とも筋力低下なく, 小脳機能検査も正常で変 換運動障害, 测定障害を認めなかった。

血液検查所見：白血球増多なく, 分画正常, CRP 陰性, 血沈充進なし, 血清 IgG, IgM, IgA 值正常, 抗核抗体陰 性, 抗 DNA 抗体陰性であった。

髄液検査: 髄液圧, 組成, 性状ともに正常で髄液細胞 診でも腫愓細胞はみられなかった。

MRI 検查: 当科受診後に撮影された MRI において, T2 強調画像で右中小脳脚から小脳橋角部にかけて高信号領 域を認め，内部には小囊胞性部位を伴っていた（図 5). 拡散強調画像でも同様の部位が高信号に描出された. T1
強調画像では病変は描出されずガドリニウムによる造影 効果も認めなかった. 前医受診時（9カ月前）の MRI 検 查を再評価した結果, 中小脳脚に T2 強調画像で高信号 の病変が描出されていた（図 6). 病変の範囲は当科で撮 影された MRI とほぼ同程度であった。臨床症状が進行性 で, その後も MRI による右中小脳脚異常陰影に変化がな いことから腫瘍性病変を最も疑い当院脳外科にて精查を 続行した.

その後の経過 : 右難聴, 顔面神経麻痺はさらに進行し 2006 年 3 月 24 日には右壟に, 表情筋スコアも 6/40 と完 全麻痺となった。確定診断のため 2006 年 3 月 30 日，開 頭下生検術が行われ, 病理組織診断により髄芽腫と診断 された。引き続き放射線療法が開始され全脳照射 $36 \mathrm{~Gy}$, 定位照射 $10 \mathrm{~Gy}$ ，全脊髄照射 $30.6 \mathrm{~Gy}$ が行われ，引き続 きCBDCA，VP-16による化学療法を行った。

現時点で治療後聴力は, 右壟のままであったが, 顔面 神経麻痺は表情筋スコア $24 / 40$ まで回復した。

$$
\text { 考察 }
$$

髄芽腫は, 小览の小脸虫部, 第 4 脳室近傍に好発し, 


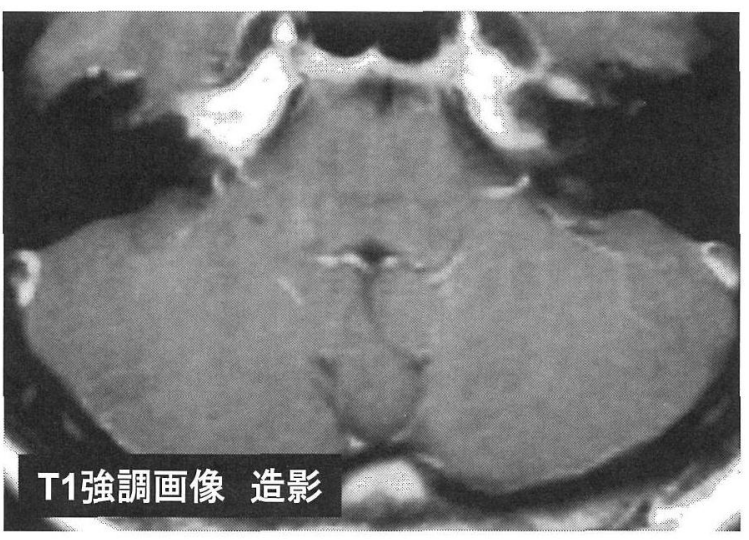

a

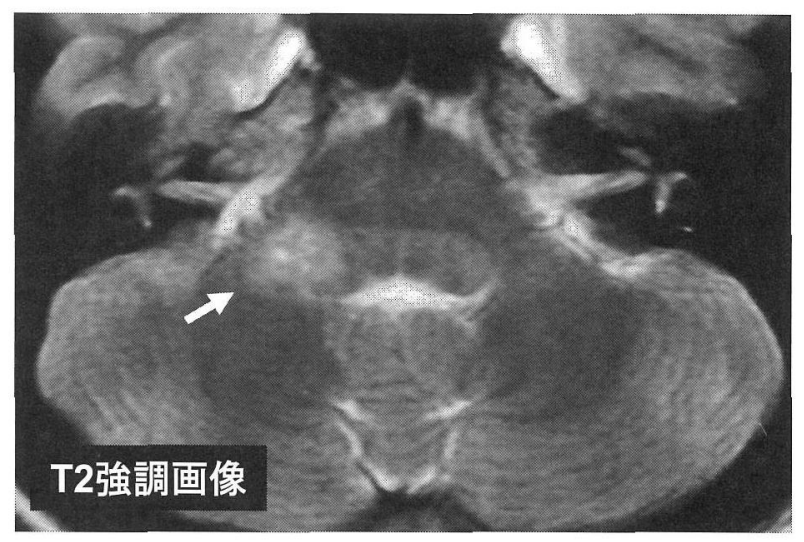

b

図 5 当科受診時に行われた MRI 検查画像（2005 年 11 月 7 日）

(a : T1 強調画像 造影, $\mathrm{b}$ ：T2 強調画像） T2 強調画像で右中小脳脚部にみられる高信号部分（矢印）は, T1 強調画像では脳幹 実質との境界が明らかでなく造影もされなかった。

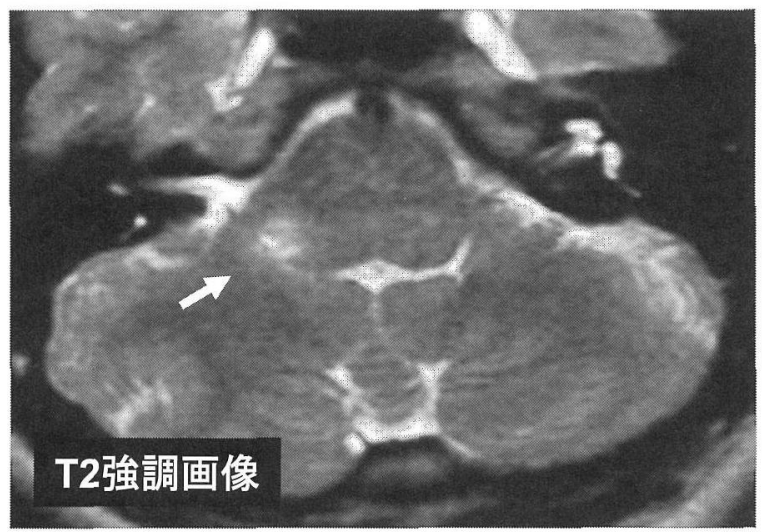

a

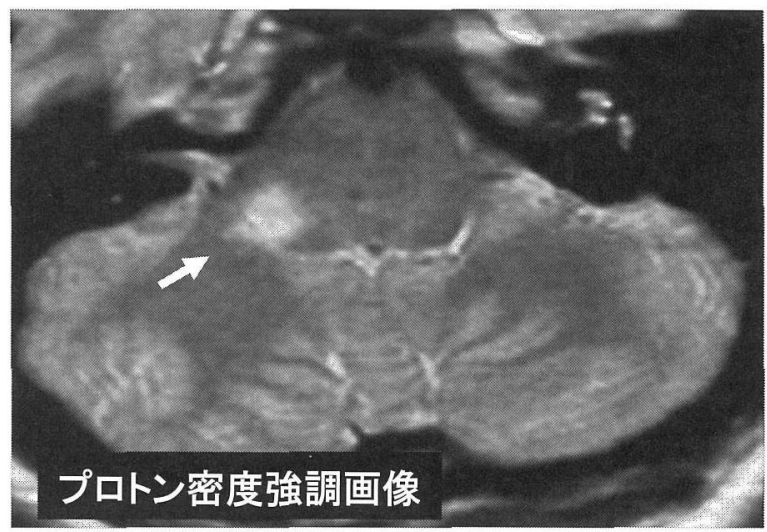

b

図 6 前医受診時に施行された MRI 検査画像（2005 年 2 月 15 日）

（a：T2 強調画像，b：プロトン密度強調画像）右中小脸脚部に高信号部分（矢印）が存在した。

髄液播種が高頻度にみられる悪性腫瘍である，小児の原 発性脳腫湟の $15 \sim 25 \%$ を占め, 約 70\%が 15 歳以下の小

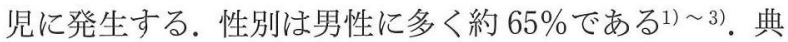
型的には小脳虫部加ら第 4 脳室を前方に圧排する腫瘤と して認められ，MRI 画像では，T1 強調画像において不 均一な軽度低信号を示し，中等度の不均一な造影効果を 示すことが多いとされるが，造影効果がそしいこともあ る。拡散強調画像で腫瘍全体が比較的に高信号を示すの が，小児に好発する後頭蓋窩腫瘍である上衣腫，星細胞 腫との鑑別点とされる3). CT 画像では単純 CT にて脳実
質より軽度高吸収を示す傾向があり，石灰化が示される 場合があるとされる゙)。

本症例の病変は脳幹部，橋下部外側から中小脳脚に限 局した髄芽腫であった。脳幹病変で一側の純音聴力検查 の異常がめまいを伴わずに単独で出現するためには螖牛 神経核そのもの加ら末梢の聴覚伝導路にがけ限局性に 傷害される必要がある。難聴を引き起こす脳幹障害は通 常，血行障害，脱髄性疾患，腫瘍性疾患で生じる。血管 性病変では急性感音難聴で発症した前下小脳動脈症候群 の報告が散見されるが，いずれも，前庭症状を伴ってい 
た ${ }^{4)}$ 。これは障害部位の範囲に加え梗塞が急性発症する ため前庭系の代償が生じにくいためと思われる，次いで 多発性硬化症は脳, 脊髄の散在性の脱髄性疾患であるが, 症候の寛解増悪がみられるのが大きな特徵である. $3 \%$ 末 満と少ないながらも急性難聴をきたし ${ }^{5)}$ ，難聴，めまい が初発症状となることがある6).

これまで脳幹の腫瘍性疾患による難聴の報告は, 肺腺 癌の脳幹転移症例 7), 組織型は不明ながら延髄を背側か ら圧迫する腫瘍性病変による進行性低音障害型感音 難聴の症例 8 , 右急性感音難聴で発症した右小脳半球の medulloblastoma が橋背部外側圧迫した症例 ${ }^{9}$, 第4脳室上 衣腫症例 ${ }^{10)}$ がある。これらの 4 症例では，いずれも症状 は進行性であった。 (1)難聴に歩行時の不安定感, 偏倚傾

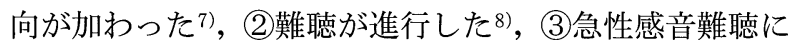
同側の顔面知覚低下を伴い，その後回転性めまいが遅れ て加わった ${ }^{9}$, (4)進行性感音難聴にふらつきを伴った ${ }^{10)}$ ことによって CT, MRI 検查が行われ, 脳幹の腫瘍性病 変を診断された。難聴が初発症状となる腫瘍性病変は圧 倒的に小脳橋角部病変が多く, 脳幹病変によって感音難 聴が初発した症例の報告は多くない。一方，純音聴力検 査異常と同時に他の脳神経症状や頭蓋内病変を示唆する 症状がすでにあり，脳幹病変が診断された症例の報告は 散見された ${ }^{11) 〜 12) . ~}$

呈示症例では難聴は進行して治療開始の時には壟とな り, 以後難聴の回復はみられなかったが，過去の脳幹腫 瘍症例の報告には聴力回復例もみられる ${ }^{9)} \sim 11$. 経過は 腫瘍の発生部位と蝸牛神経核を含む聴覚伝導路との位置 関係によるが, 難聴が唯一の症状の場合, 病変は蝸牛神 経核により近く存在している可能性が高い。したがって 蝸牛神経核が腫瘍によって直接破壊されていれば難聴の 回復は期待できない．また，ABR にてI波が検出されな かったことから, 橋における蝸牛神経線維の障害も示唆 された。

初診時のオージオグラムは低音障害型感音難聴を示し た。これまで脳幹の腫瘍性病変で低音障害型感音難聴を 示した症例は本症例以外にも報告されていて ${ }^{8122}$, 内リ ンパ水腫による蝸牛障害と短絡的に考えることの危険性 が示された。一方, 脳幹病変に特徵的なオージオグラム はないともいわれている12).

本症例を確定診断後に典型的な後迷路性難恥というの は簡単であるが，当科受診前に少ない情報で後迷路性病 変を疑うのは易しいことではなかったはずである. 現病
歴から緩徐進行病変の可能性を重視し前医により早期に MRI 検査が施行された. MRI 検查の施行時期は判断の難 しいところで，一側性の感音難聴では MRI の適応の判断 を常に迫られる。急性低音障害型感音難聴症例は，40 歳 代をピークに女性に多く ${ }^{13)}$, 非治癒例, 再発例も報告さ れる. 症例は 25 歳の女性で, 急性低音障害型感音難聴の 好発年齢であるといえる. 後迷路性病変によって一側性 低音障害型の感音難聴を発症する確率は低く, 医療効率 の観点からも詳細な問診や検查を踏まえて適応を判断す るのが妥当であると考える.

今回の報告では前医で MRI 検查が施行され, 病変が描 出されていたにもかかわらず見逃された．前医での MRI を複数の医師が異常なしと判断したが, 当院でも新たな 病変を探す目的で MRI 検查を行った。 その結果, 当院の 放射線科医によって脳幹病変が指摘された. 前医の所属 する病院の放射線科医による報告書が, 前医, 当院の耳 鼻科医の判断に大きな影響を与えた可能性は否定できな いが, 後迷路性難聴に関する一般的な耳鼻科医の理解が そしい可能性もある.このような状沉で MRI 検查を施行 する際には聴神経腫煬を見逃さないといらことに多大な 関心が払われ，脳幹には注意が向けられない可能性や， 解剖学的, 画像診断学的知識不足がある場合もある.

対策は，放射線科の報告を鵜吞みにすることなく，聴 覚障害が生じるメカニズムを再確認することが有用であ り, 解剖学的な知識と画像検查所見が対応する聴覚伝導 路を常にMRI画像の中でイメージできるよう心がけるべ きである. また 3DAC MRX 法等の MRI 撮像法の工夫に よる聴覚伝導路の描出画像は, 聴覚伝導路を解剖図と対 比して確認することが可能で, 理解を深めるのに役立 $\supset^{14)}$. 呈示症例では，病変は蝸牛神経核そのもの，ある いは近接して原発し, 病変の進行に伴い顔面神経核にも 障害が及んだと考えられた。

感音難聴の診断にあたっては, 後迷路性難聴の可能性 を常に念頭に置く必要がある. 診断に MRI 検査が最も重 要な役割を果たすことに疑いはないが, 全例に MRI を行 うことは過剩で，スクリーニングとして画像診断以外の 検查を適宜実施することも重要である。特に ABR は聴 神経腫瘍の診断にも有用で ${ }^{15)}$, 非侵襲的に行える点でも 優れた検查である.今回の症例では ABR, 視運動性眼振 検査, 視標追跡運動検查にも異常がみられ，これら機能 検査の有用性が再確認された。 


\section{まとめ}

右低音障害型感音難聴が初発症状であった橋の髄芽腫 症例を報告した。病初期には後迷路性病変を疑わせる所 見に乏しいが, 進行性の感音難聴では MRI 検查の適応を 検討する必要がある，近年，画像検査は進歩が著しく， 結果を正確に評価するためには高度な画像診断能力の獲 得・維持の重要性が改めて認識された。一方で詳細な問 診, 神経耳科学的検查は画像診断技術が進歩しても依然 として重要であると思われた。

本論文の要旨は第 68 回耳鼻咽喉科臨床学会 $(2006$ 年 6 月, 金 沢）において報告した。

\section{参考文献}

1) Packer RJ, Cogen P, Vezina G, et al. : Medulloblastoma: Clinical and biologic aspects. Neuro-oncol 1:232 250, 1999.

2）日向野修一, 田村 元, 麦倉俊司, 他: マルチスライス CT と MRI の臨床応用 頭部 - 頭頸部 脳腫瘍. 診断と治療 $92: 1511 \sim 1523,2004$.

3）日向野修一：髄芽腫. 脳腫瘍 頭部画像診断のここが鑑別 ポイント (土屋一洋, 大久保敏之編). $76 \sim 77$ 頁, 羊土社, 東京, 2005 .

4）那須 隆, 中村 正, 横田雅司, 他: 急性感音難聴で発症 した脳幹梗塞の 1 例. Equibrium Res $57: 289 \sim 296,1998$.

5) Fischer $\mathrm{C}$, Mauguière $\mathrm{F}$, Ibanez $\mathrm{V}$, et al. : The acute deafness of definite multiple sclerosis: BAEP patterns. Electroencephalogr Clin Neurophysiol 61: $7 \sim 15,1985$.

6) Gstoettner W, Swoboda H, Müller C, et al. : Preclinical detection of initial vestibulocochlear abnormalities in a patient with multiple sclerosis. Eur Arch Otorhinolaryngol $250: 40 \sim 43$, 1993.

7) Tsutsumi S, Horinaka N, Mori K, et al. : Metastatic brainstem tumor manifesting as hearing disturbance-case report-. Neurol Med Chir (Tokyo) $41: 561 \sim 564,2001$.

8）張 暁彦, 伊藤真人, 能登谷晶子, 他：進行性の低音障害 型感音難聴をきたした脳幹部腫瘍. Audiol Jpn $42: 56$ 〜 57, 1999.

9) Merino Gálvez E, Hellín Meseguer D, García Ortega F, et al. : Sudden deafness and cerebellar tumour. J Laryngol Otol 108 : $584 \sim 586,1994$.

10）山本昌範，矢部多加夫，石井甲介，他：進行性感音難聴を 呈し聴神経腫瘍が疑われた第 4 脳室上衣腫症例. Equibrium Res $64: 76 \sim 82,2005$.

11）船井洋光, 北原伸郎, 林田哲郎：橋グリオーマ 5 症例にみ られた聴性誘発反応所見. Audiol Jpn 38:87〜95, 1995.

12）永瀬茂代，伊藤真郎，木村 仁，他：低音障害型感音難聴 を示した脳幹腫瘍例. 耳鼻臨床 $83: 1337 \sim 1342,1990$.

13）阿部 隆：急性低音障害型感音難聴の診断. Audiol Jpn 49: $8146 \sim 155,2006$.

14）泉 修司, 中田 力：聴覚神経学の MRI. 神経進歩 48： $234 \sim 238,2004$.

15）佐藤 斎, 藤暗俊之, 和田匡史, 他 : 純音聴力閾值正常の 聴神経腫瘍症例の検討. Otol Jpn $14: 165 \sim 170,2004$.

原稿受付：平成19年 2 月 14 日

原稿採択：平成19年 4 月 5 日 別刷請求先：佐藤 斎

T951-8510 新潟市中央区旭町通1 新潟大学医学部耳鼻咽喉科学講座 